\title{
ANALISIS FAKTOR-FAKTOR YANG MEMPENGARUHI TINGKAT HARGA PERUMAHAN DI KABUPATEN BULELENG
}

\author{
Bagus Sarjana1, Made Ary Meitriana². I Wayan Suwendra ${ }^{3}$ \\ Jurusan Pendidikan Ekonomi \\ Universitas Pendidikan Ganesha \\ Singaraja, Indonesia \\ e-mail: bagussarjana@ymail.com¹, ary.meitriana@yahoo.co.id², \\ yc9eda@yahoo.co.id ${ }^{3}$
}

\begin{abstract}
Abstrak
Tujuan penelitian ini adalah untuk mengetahui faktor yang mempengaruhi tingkat harga perumahan di Kabupaten Buleleng dan faktor yang paling dominan mempengaruhi tingkat harga perumahan di Kabupaten Buleleng. Jenis penelitian ini adalah penelitian kuantitatif dengan menggunakan rancangan penelitian faktorial. Subjek penelitian ini adalah developer yang bergerak di bidang properti yang ada di Kabupaten Buleleng dengan jumlah 36 developer. Pengumpulan data menggunakan kuesioner dianalisis menggunakan analisis faktor berbantuan program SPSS 24.0 for Windows. Hasil penelitian menunjukkan bahwa faktor-faktor yang mempengaruhi tingkat harga perumahan di Kabupaten Buleleng adalah faktor keadaan perekonomian memiliki eigenvalue 1.195 dengan nilai varian $17.073 \%$, faktor permintaan dan penawaran memiliki eigenvalue 1.024 dengan nilai varian $14.622 \%$, faktor elastisitas permintaan memiliki eigenvalue 0.433 dengan nilai varian $6.180 \%$, faktor persaingan memiliki eigenvalue 0.175 dengan nilai varian $2.495 \%$, faktor biaya memiliki eigenvalue 2.818 dengan nilai varian $40.262 \%$, faktor tujuan perusahaan memiliki eigenvalue 0.762 dengan nilai varian $10.882 \%$, dan faktor pengawasan pemerintah memiliki eigenvalue 0.594 dengan nilai varian $8.486 \%$. Faktor yang paling dominan mempengaruhi tingkat harga perumahan di Kabupaten Buleleng adalah faktor biaya dengan varimax rotation sebesar $40.262 \%$.
\end{abstract}

Kata kunci: tingkat harga perumahan, analisis faktor.

\begin{abstract}
The purpose of this research was to determine the factors that influence the level of housing prices in Buleleng Regency and the most dominant factor influence the level of housing prices in Buleleng Regency. This type of research was quantitative research with factorial research design. The subject of this research were developer engaged in property in Buleleng Regency with 36 developers. Data collection used questionnaire analyzed using factor analysis supported by SPSS 24.0 for Windows program. The result of the research shows that the factors that influence the level of housing prices in Buleleng Regency were factors of the economy had eigenvalues 1,195 with variance value $17,073 \%$, demand and supply factors had eigenvalue 1,024 with variance value $14,622 \%$, demand elasticity factor had eigenvalue 0.433 with variance value $6.180 \%$, factor competition had eigenvalues 0.175 with variance value $2.495 \%$, cost factor had eigenvalues 2,818 with variance value $40,262 \%$, company objective factors had eigenvalues 0.762 with variance value $10.882 \%$, and government supervision factors had eigenvalues 0.594 with variance value $8.486 \%$.
\end{abstract}

Keywords: level of housing prices, factor analysis. 


\section{PENDAHULUAN}

Sebutan/istilah mengenai harga untuk berbagai produk tidak selalu sama dan dengan berbagai nama, Menurut Kotler dan Amstrong (2008) mendefinisikan harga adalah sejumlah uang yang ditagihkan atas suatu produk dan jasa atau jumlah dari nilai yang ditukarkan para pelanggan untuk memperoleh manfaat dari memiliki atau menggunakan suatu produk atau jasa. Harga adalah unsur penting dalam sebuah perusahaan dimana dengan adanya harga maka perusahaan akan mendapatkan income bagi keberlangsungan perusahaan. Selain itu, harga juga merupakan alat yang nantinya dijadikan proses pertukaran terhadap suatu barang atau jasa oleh konsumen.

Dalam kehidupan bisnis, Kotler dan Armstrong (2012) mengemukakan, tingkat harga adalah rate yaitu angka yang menunjukkan nilai, harga, kecepatan perkembangan, dan produksi bedasarkan satuan ukur tertentu, biaya premi, asuransi ataupun beban biaya. Tinggi rendahnya tingkat harga selalu menjadi perhatian utama para konsumen saat mereka mencari suatu produk. Sehingga harga yang ditawarkan menjadi bahan pertimbangan khusus, sebelum mereka memutuskan untuk membeli barang maupun menggunakan suatu jasa. Dari kebiasaan para konsumen, strategi penetapan tingkat harga sangat berpengaruh terhadap penjualan maupun pemasaran produk yang ditawarkan. Dalam menentukan tingkat harga, setiap pengusaha memiliki strategi yang berbedabeda.

Menurut Swastha dan Irawan (2005) penentuan tingkat harga tidak hanya ditentukan oleh perusahaan tetapi konsumen pun juga ikut serta dalam penentuan harga, perusahaan menentukan harga jual dengan dipengaruhi beberapa faktor yang berhubungan dengan keadaan ekonomi di wilayah tersebut, permintaan, elastisitas permintaan, persaingan dengan perusahaan lain, biaya, tujuan perusahaan, kebijakan dari pemerintah. Dari sisi konsumen penentuan harga dipengaruhi oleh penawaran suatu barang dari sebuah perusahaan. Selanjutnya Kotler (2002) mengemukakan terdapat 4 faktor yang mempengaruhi perusahaan dalam menetapkan tingkat harga untuk produknya diantaranya kurva permintaan, dimana kurva yang menunjukkan tingkat pembelian pasar pada berbagai harga, kurva tersebut menjumlahkan reaksi berbagai individu yang memiliki kepekaan pasar yang beragam, faktor selanjutnya yaitu biaya, merupakan faktor penting dalam menentukan tingkat harga minimal yang harus ditetapkan agar perusahaan tidak mengalami kerugian, faktor lainnya yaitu persaingan, dan faktor terakhir yaitu pelanggan.

Penjualan dalam bidang properti seperti rumah, untuk menentukan tingkat harga maka perusahaan harus menghitung dengan cermat dan menentukan metode penentuan tingkat harga yang tepat. Perusahaan harus menentukan tingkat harga dengan sangat hati-hati dikarenakan harga jual rumah selalu meningkat terusmenerus dan hampir tidak pernah turun dalam jangka waktu yang pendek maupun panjang. Oleh karena itu untuk menjadi perusahaan yang unggul di bidang properti ini, perusahaan tersebut harus mampu mengadaptasi dan mengantisipasi setiap perubahan yang terjadi di dalam lingkungan yaitu dengan cara memberikan respon yang tepat. Respon yang dimaksud biasanya hanya dapat dilakukan oleh suatu perusahaan yang mampu melihat faktorfaktor apa saja yang dapat mempengaruhi naik turunnya daya jual dari suatu perusahaan tersebut salah satu contohnya ialah faktor-faktor dari penentuan tingkat harga tersebut.

Hasil observasi awal yang peneliti lakukan mengenai tingkat harga perumahan di Kabupaten Buleleng, peneliti menemukan perusahaan properti, yaitu Arjuna Properti yang berada di Kecamatan Seririt menetapkan rumah tipe 34/75 dengan harga Rp 250.000.000/unit, yang merupakan wilayah yang jauh dari kota Singaraja, begitu pula perusahaan properti yaitu Taman Wira Sambangan yang berada di Kecamatan Sukasada menetapkan rumah tipe 36/84 dengan harga $\mathrm{Rp}$ 325.000.000/unit, sedangkan perusahaan properti yaitu PT. Ambara Raja Properti yang berada di Kecamatan Buleleng dimana wilayah tersebut merupakan 
wilayah yang sangat dekat dengan kota menetapkan rumah tipe $36 / 70$ dengan harga Rp 141.000.000/unit.

Berdasarkan hasil observasi tersebut dapat diidentifikasi masalah bahwa dengan tipe rumah yang relatif sama ternyata ada perbedaan harga perumahan yang cukup tinggi. Kemudian, dapat diidentifikasi masalah lainnya bahwa perumahan yang lebih dekat dengan kota Singaraja harganya ditetapkan lebih murah daripada perumahan yang relatif lebih jauh dari kota Singaraja. Dari permasalahan tersebut peneliti sementara menduga bahwa ada faktor-faktor yang mempengaruhi perbedaan tingkat harga perumahan di Kabupaten Buleleng. Secara teoritis, menurut pendapat Swastha dan Irawan (2005), ada 7 faktor yang mempengaruhi tingkat harga, yaitu keadaan perekonomian, permintaan dan penawaran, elastisitas permintaan, persaingan, biaya, tujuan perusahaan, dan pengawasan pemerintah. Faktor tersebut diduga sementara dapat mempengaruhi harga perumahan, sehingga hal inilah yang menjadikan alasan peneliti untuk mengkaji faktor-faktor apa saja yang mempengaruhi tingkat harga perumahan. Dengan demikian, penulis tertarik untuk melaksanakan penelitian dengan judul "Analisis Faktor-faktor yang Mempengaruhi Tingkat Harga Perumahan di Kabupaten Buleleng."

\section{METODE}

Penelitian ini dilakukan untuk
mengetahui mempengaruhi tingkat harga perumahan di Kabupaten Buleleng dan mengetahui faktor yang dominan mempengaruhi tingkat harga perumahan di Kabupaten Buleleng. Penelitian ini menggunakan rancangan penelitian faktorial.

Penelitian ini dilakukan pada developer yang bergerak di bidang properti yang ada di Kabupaten Buleleng. Populasi adalah wilayah generalisasi yang terdiri dari obyek/subjek yang mempunyai kualitas dan karakteristik tertentu yang ditetapkan oleh peneliti untuk dipelajari dan kemudian ditarik kesimpulannya (Sugiyono, 2011). Populasi pada penelitian ini adalah developer yang bergerak di bidang properti yang ada di Kabupaten Buleleng dengan jumlah 36 developer. Sampel adalah bagian dari jumlah dan karakteristik yang dimiliki oleh populasi (Sugiyono, 2011). Apabila populasi kurang dari 100 orang, maka sebaiknya semua dijadikan sebagai sasaran penelitian (Arikunto, 2009). Oleh karena itu, penelitian ini merupakan penelitian populasi atau penelitian sampel jenuh, yang artinya semua populasi dijadikan sebagai sampel penelitian. Populasi pada penelitian ini adalah developer yang bergerak di bidang properti yang ada di Kabupaten Buleleng dengan jumlah 36 developer sehingga sampel dari penelitian ini juga berjumlah 36 developer.

Jenis data yang digunakan dalam penelitian ini adalah data kuantitatif, yaitu data yang dapat dihitung. Dalam penelitian ini yang termasuk dalam data kuantitatif adalah data hasil jawaban kuesioner mengenai faktor-faktor yang mempengaruhi tingkat harga perumahan di Kabupaten Buleleng. Sumber data yang digunakan adalah data primer. Data dikumpulkan secara langsung dari responden yang diperoleh dengan cara memberikan daftar pertanyaan yang berupa kuesioner mengenai faktor-faktor yang mempengaruhi tingkat harga perumahan di Kabupaten Buleleng. Metode pengumpulan data yang digunakan dalam penelitian ini adalah kuesioner. Kuesioner tersebut diberikan kepada para responden dan kemudian diharapkan setiap masing-masing responden akan mengisinya dengan pendapat dan persepsi setiap individu responden itu sendiri.

Kuesioner diberikan langsung kepada responden, kemudian responden memilih salah satu dari alternatif jawaban yang telah tersedia. Kuesioner ditunjukan kepada developer yang bergerak di bidang properti yang ada di Kabupaten Buleleng. Instrumen penelitian digunakan berdasarkan konsep dasar dari teori yang mendasari dari variabel-variabel penelitian. Instrumen dalam penelitian ini terdiri dari pertanyaanpertanyaan dikembangkan dari indikator dengan masalah yang diteliti. Berdasarkan pada indikator yang terdapat di dalam jabaran variabel, maka dapat disusun dan dikembangkan menjadi instrumen penelitian yang berupa kuesioner atau angket. Skala pengukuran yang digunakan adalah skala 
Likert dengan lima alternatif jawaban. Variabel dalam penelitian yang telah ditetapkan akan dijabarkan menjadi indikator, dan dari indikator ini kemudian dijabarkan sebagai titik tolak untuk menyusun item intrumen yang kemudian diubah dalam beberapa pertanyaan yang selanjutnya dijawab oleh responden.

Kuesioner sebagai instrumen pengumpulan data terlebih dahulu harus diuji tingkat validitas dan reliabilitasnya. Data yang didapat dari kuesioner adalah data ordinal. Agar dapat diuji, maka data tersebut diubah menjadi data interval melalui Method of Successive Interval dengan bantuan program Microsoft Office Excel 2007. Untuk menguji tingkat validitas dan reliabilitas instrumen penelitian akan diujikan kepada 30 responden. Uji validitas digunakan untuk mengukur valid tidaknya suatu kuesioner. Kuisioner dikatakan valid apabila kuisioner mampu untuk mengungkapkan dengan pasti apa yang akan diteliti. Pengujian validitas dalam penelitian ini dilakukan dengan menggunakan korelasi Corrected Item-Total Correlation yang terdapat dalam program SPSS 24.0 for Windows. Suatu pertanyaan dikatakan valid jika $r_{\text {hitung }}>r_{\text {tabel }}$ dan kuisioner dikatakan tidak valid apabila ritung $<r_{\text {tabel. }}$. Reliabilitas menunjuk pada satu pengertian bahwa suatu instrumen cukup dapat dipercaya untuk digunakan sebagai alat pengumpulan data karena instrumen tersebut sudah baik. Dalam penelitian ini pengujian reliabilitas instrumen dilakukan dengan membandingkan nilai Cronbach Alpha yang diperoleh dari SPSS 24.0 for Windows dengan batas nilai Crombach Alpha untuk mengukur instrumen yang reliabel. Pengujian statistik dengan menggunakan teknik statistik Cronbach Alpha instrumen dikatakan reliabel untuk mengukur variabel apabila memiliki nilai Cronbach Alpha lebih > 0,60. Hasil uji validitas pada kuesioner keadaan perekonomian 5 item dinyatakan valid, kuesioner permintaan dan penawaran 8 item dinyatakan valid, kuesioner elastisitas permintaan 4 item dinyatakan valid, kuesioner persaingan 2 item dinyatakan valid, kuesioner biaya 5 item dinyatakan valid, kuesioner tujuan perusahaan 6 item dinyatakan valid, dan kuesioner pengawasan pemerintah 4 item dinyatakan valid. Hasil uji reliabilitas menunjukan kuesioner keadaan perekonomian, permintaan dan penawaran, elastisitas permintaan, persaingan, biaya, tujuan perusahaan, dan pengawasan pemerintah memiliki Alpha Cronbach $>0,60$ sehingga kuesioner dinyatakan reliabel.

Sesuai dengan rumusan masalah, tujuan penelitian dan juga jenis data yang dikumpulkan, maka metode analisis data yang digunakan dalam penelitian ini adalah model analisis faktor. Metode analisis faktor merupakan metode yang digunakan untuk mereduksi data atau meringkas dari variabel yang banyak diubah menjadi variabel yang jumlahnya lebih sedikit (Sulianto, 2012). Analisis faktor digunakan untuk mereduksi dan meringkas dari banyak variabel ke dalam satu atau beberapa faktor, dengan menggunakan program SPSS 24.0 for Windows. Dalam analisis faktor terdiri lima tahap, yaitu sebagai berikut. Pertama, semua data yang masuk dan diolahakan mengahasilkan matrik korelasi. Matrik korelasi dapat diidentifikasi variabel-variabel tertentu yang tidak mempunyai korelasi dengan variabel yang lain, sehingga dapat dikeluarkan dari analisis. Untuk menguji ketepatan model analisis faktor, maka dapat digunakan Barlett's test of Sphericity yang dipakai untuk menguji bahwa variabel-variabel dalam sampel berkolerasi. Hasil Barlett's test of Sphericity menunjukan apakah hubungan antara variabel-variabel signifikan atau tidak. Statistik lain yang berguna adalah pengukuran kelayakan sampai Kaiser Meyer Olkin (KMO). Analisis faktor dianggap layak jika besaran KMO nilainya minimal 0,50. Besaran ini digunakan untuk mengukur derajat korelasi antara variabel dengan Kriteria Mesure of Sampling Adequacy (MSA) $\geq 0,50$. Kedua, menentukan jumlah faktor. Variabel disusun kembali berdasarkan pada korelasi hasil langkah pada butir dua untuk menentukan faktor yang diperlukan untuk mewakili data. Untuk menntukan berapa faktor yang dapat diterima secara empiric dapat dilakukan berdasarkan besarnya eigenvalue setiap faktor yang muncul. Semakin besar eigenvalue setiap faktor, semakin representatif faktor faktor tersebut untuk 
p-ISSN : 2599-1418

e-ISSN : 2599-1426

mewakili sekelompok variabel. Faktor-faktor ini dipilih adalah faktor yang mempunyai eigenvalue sama dengan atau lebih dari satu. Ketiga, rotasi faktor. Hasil penyederhanaan faktor dalam marik faktor memperlihatkan hubungan antara faktor dengan variabel individu, tetapi dalam faktor-faktor tersebut terdapat banyak variabel yang berkorelasi sehingga sulit diinterpretasikan. Dengan menggunakn rotasi faktor matrik, matrik faktor ditranspormasikan ke dalam matrik yang lebih sederhana sehinga mudah untuk diinterpretasikan. Dalam perilaku ini digunakan rotasi varimax. Keempat, interprestasi faktor. Interprestasi faktor dilakukan dengan mengelompokan variabel yang mempunyai faktor loading tinggi ke dalam faktor tersebut. Untuk menginterpretasikan hasil penelitian ini faktor loading minimal 0.5 . Variabel yang mempunyai faktor loading kurang dari 0,5 dikeluarkan dari model. Kelima, mentukan penetapan model. Tahap terahir dari analisis faktor adalam mengetahui apakah model mampu menjelaskan dengan baik. Fenomena yang ada perlu diuji dengan teknik Princapal Component Analisis, yaitu dengan melihat jumlah residual antara korelasi yang diamati dengan korelasi yang direproduksi, dalam penelitian ini, tuk mempermudah proses perhitungan dan untuk mendapatka hasil perhitungan yang akurat dalam analisis data, penelitian
Jurnal Pendidikan Ekonomi Undiksha

Volume 10 No. 2 Tahun 2018

mengunakan bantuan alat hitung berupa program SPSS 24.0 for Windows.

Hipotesi konseptual akan dianalisis dengan menggunakan analais faktor dengan langkah-langkah sebagai berikut. Pertama, menguji matrik korelasi dengan mengunakan Barlett's Sphericity dengan koefisien KMO yang telah tersedia dalam SPSS 24.0 for Windows. Jika hasil pengujian statistik Barlett's Sphericity signifikan dan hasil perhitungan koefisien $\mathrm{KMO}>0,5$. maka persyaratan pengujian analisis faktor untuk menentukan faktor yang menjelaskan komponen utama yang memiliki parameter karakteristik terkecil (eigenvalue). Kedua, untuk menetukan dimensi atau faktor kebrhasilan usaha yang paling mendominasi pada faktor maka digunakan parameter koefisien varimax rotation dari dimensi atau faktor keberhasilan usaha yang paling mendekati +1 atau mendekati -1 .

\section{HASIL DAN PEMBAHASAN}

Berdasarkan hasil analisis data menunjukkan bahwa faktor-faktor yang mempengaruhi tingkat harga perumahan di Kabupaten Buleleng dapat dijelaskan oleh persentase dari masing-masing faktor. Nilai Total Variance Explained digunakan untuk mengetahui persentase dari faktor-faktor yang dianalisis. Hasil analisis faktor persentase dari masing-masing faktor dapat dilihat pada Tabel 1.

Tabel 1. Hasil Analisis Total Variance Explained

\begin{tabular}{|c|c|c|c|c|c|c|}
\hline \multirow{3}{*}{ Component } & \multicolumn{5}{|c|}{ Total Variance Explained } & \\
\hline & \multicolumn{3}{|c|}{ Initial Eigenvalues } & \multicolumn{2}{|c|}{ Extraction Sums of Squared Loadings } & \\
\hline & Total & $\%$ of Variance & Cumulative \% & Total & $\%$ of Variance & Cumulative \% \\
\hline $\begin{array}{l}\text { Keadaan } \\
\text { perekonomian }\end{array}$ & 1.195 & 17.073 & 17.073 & 1.195 & 17.073 & 17.073 \\
\hline $\begin{array}{l}\text { Permintaan dan } \\
\text { penawaran }\end{array}$ & 1.024 & 14.622 & 31.695 & 1.024 & 14.622 & 31.695 \\
\hline $\begin{array}{l}\text { Elastisitas } \\
\text { permintaan }\end{array}$ & 0.433 & 6.180 & 37.875 & & & \\
\hline Persaingan & 0.175 & 2.495 & 40.371 & & & \\
\hline Biaya & 2.818 & 40.262 & 80.633 & 2.818 & 40.262 & 71.957 \\
\hline $\begin{array}{l}\text { Tujuan } \\
\text { perusahaan }\end{array}$ & 0.762 & 10.882 & 91.514 & & & \\
\hline $\begin{array}{l}\text { Pengawasan } \\
\text { pemerintah }\end{array}$ & 0.594 & 8.486 & 100.000 & & & \\
\hline
\end{tabular}

Extraction Method: Principal Component Analysis. 
Berdasarkan Tabel 1 dapat ditunjukkan bahwa faktor keadaan perekonomian memiliki eigenvalue sebesar 1.195 dengan nilai varian sebesar $17.073 \%$, faktor permintaan dan penawaran memiliki eigenvalue sebesar 1.024 dengan nilai varian sebesar $14.622 \%$, faktor elastisitas permintaan memiliki eigenvalue sebesar 0.433 dengan nilai varian sebesar $6.180 \%$, faktor persaingan memiliki eigenvalue sebesar 0.175 dengan nilai varian sebesar $2.495 \%$, faktor biaya memiliki eigenvalue sebesar 2.818 dengan nilai varian sebesar $40.262 \%$, faktor tujuan perusahaan memiliki eigenvalue sebesar 0.762 dengan nilai varian sebesar $10.882 \%$, dan faktor pengawasan pemerintah memiliki eigenvalue sebesar 0.594 dengan nilai varian sebesar $8.486 \%$.

Faktor yang dapat menjelaskan tingkat harga perumahan dapat ditunjukkan dengan ekstraksi faktor. Ekstraksi faktor dapat dijelaskan oleh total persentase dari masing-masing faktor utama. Faktor-faktor utama tersebut adalah biaya, keadaan perekonomian, serta permintaan dan penawaran yang memiliki eigenvalue $>1$. Untuk mengetahui distribusi dimensidimensi yang belum dirotasi ke dalam faktor yang telah terbentuk, maka dapat dilihat pada Rotated Component Matrix seperti pada Tabel

Tabel 2. Faktor yang Menjelaskan Tingkat Harga Perumahan di Kabupaten Buleleng

\begin{tabular}{|c|c|c|c|}
\hline Faktor & Eigenvalues & $\begin{array}{c}\text { Variance } \\
\text { Explained (\%) }\end{array}$ & $\begin{array}{l}\text { Loading } \\
\text { Factor }\end{array}$ \\
\hline Keadaan perekonomian & 1.195 & 17.073 & 0.871 \\
\hline Permintaan dan penawaran & 1.024 & 14.622 & 0.822 \\
\hline Elastisitas permintaan & 0.433 & 6.180 & 0.733 \\
\hline Persaingan & 0.175 & 2.495 & 0.543 \\
\hline Biaya & 2.818 & 40.262 & 0.939 \\
\hline Tujuan perusahaan & 0.762 & 10.882 & 0.846 \\
\hline Pengawasan pemerintah & 0.594 & 8.486 & 0.774 \\
\hline
\end{tabular}

Berdasarkan Tabel 2 ditunjukkan bahwa faktor yang memiliki eigenvalue $>1$ adalah faktor biaya, keadaan perekonomian, serta permintaan dan penawaran. Nilai varianced explained faktor biaya sebesar $40.262 \%$, keadaan perekonomian sebesar $17.073 \%$, permintaan dan penawaran sebesar $14.622 \%$. Total nilai varianced explained dari ketiga faktor keseluruhan sebesar $71.957 \%$. Dengan demikian, $71.957 \%$ dari seluruh variabel yang ada dapat dijelaskan oleh 3 faktor yang terbentuk. Faktor biaya memiliki varianced explained $40.262 \%$, artinya faktor biaya mempengaruhi tingkat harga perumahan sebesar $40.262 \%$. Faktor keadaan perekonomian memiliki varianced explained $17.073 \%$, artinya faktor keadaan perekonomian mempengaruhi tingkat harga perumahan sebesar $17.073 \%$. Faktor permintaan dan penawaran memiliki varianced explained $14.622 \%$, artinya faktor permintaan dan penawaran mempengaruhi tingkat harga perumahan sebesar $14.622 \%$.

Tabel 3. Rotated Component Matrix

\begin{tabular}{lccc}
\hline \multicolumn{1}{c}{ Faktor } & \multicolumn{3}{c}{ Component } \\
\cline { 2 - 4 } Keadaan perekonomian & 1 & 2 & 3 \\
Permintaan dan penawaran & -0.009 & 0.871 & 0.088 \\
Elastisitas permintaan & -0.016 & 0.012 & 0.822 \\
Persaingan & 0.236 & 0.118 & 0.733 \\
Biaya & 0.495 & 0.543 & -0.142 \\
Tujuan perusahaan & 0.939 & 0.050 & 0.165 \\
Pengawasan pemerintah & 0.846 & 0.265 & 0.142 \\
\hline
\end{tabular}


Penentuan nama faktor yang telah terbentuk untuk masing-masing faktor bersifat subjektif, sebagian besar variabel yang memiliki nilai loading factor tertinggi digunakan untuk memberi nama faktor. Untuk melihat nilai loading factor dapat dilihat pada Tabel 3. Berdasarkan tabel 3 dapat ditunjukkan bahwa faktor yang mempengaruhi tingkat harga perumahan dapat dikelompokan menjadi 3 faktor. Faktor 1 terbentuk dari faktor biaya (X5) dengan loading factor sebesar 0.939 dan faktor tujuan perusahaan (X6) dengan loading factor sebesar 0.846. Faktor 2 terbentuk dari keadaan perekonomian (X1) dengan loading factor sebesar 0.871 , faktor pengawasan pemerintah (X7) dengan loading factor sebesar 0.774 , dan faktor persaingan (X4) dengan loading factor sebesar 0.543. Faktor 3 terbentuk dari faktor permintaan dan penawaran (X2) dengan loading factor sebesar 0.822 dan faktor elastisitas permintaan (X3) dengan loading factor sebesar 0.733 .

Penentuan faktor yang paling dominan mempengaruhi tingkat harga perumahan menggunakan koefisien varimax. Secara lebih rinci hasil ringkasan rotasi dari matriks faktor memuat nilai varimax rotation dapat dilihat pada tabel 4 .

Tabel 4. Matriks Rotasi Hasil Anallisis Faktor

\begin{tabular}{lccc}
\hline \multicolumn{1}{c}{ Dimensi atau Faktor yang } & \multicolumn{3}{c}{ Varimax Rotation (\%) } \\
Mempengaruhi Tingkat Harga & $(1)$ & $(2)$ & $(3)$ \\
\hline Biaya & 40.262 & - & - \\
Keadaan perekonomian & - & 17.073 & 14.622 \\
Permintaan dan penawaran & - & - & \\
\hline
\end{tabular}

Berdasarkan tabel 4 dapat ditunjukkan bahwa faktor yang paling dominan mempengaruhi tingkat harga perumahan di Kabupaten Buleleng adalah faktor biaya dengan varimax rotation sebesar $40.262 \%$.

Berdasarkan hasil analisis faktor diperoleh bahwa faktor-faktor yang mempengaruhi tingkat harga perumahan di Kabupaten Buleleng adalah keadaan perekonomian, permintaan dan penawaran, elastisitas permintaan, persaingan, biaya, tujuan perusahaan, dan pengawasan pemerintah. Hal ini sesuai dengan teori yang dikemukakan oleh Swastha dan Irawan (2005) bahwa ada 7 faktor yang mempengaruhi tingkat harga, yaitu keadaan perekonomian, permintaan dan penawaran, elastisitas permintaan, persaingan, biaya, tujuan perusahaan, dan pengawasan pemerintah. Hasil penelitian ini didukung oleh penelitian yang dilakukan oleh Hidayah (2011), yang menyatakan bahwa faktorfaktor yang mempengaruhi tingkat harga antara lain keadaan perekonomian, permintaan dan penawaran, elastisitas permintaan, persaingan, biaya, tujuan perusahaan, dan pengawasan pemerintah. Hasil penelitian juga menunjukkan bahwa faktor-faktor utama yang mempengaruhi tingkat harga perumahan di Kabupaten Buleleng dapat dilihat dari faktor biaya, keadaan perekonomian, dan permintaan dan penawaran.

Faktor biaya, keadaan perekonomian, serta permintaan dan penawaran merupakan faktor yang dominan mempengaruhi tingkat harga perumahan di Kabupaten Buleleng. Faktor biaya paling dominan dibandingkan faktor yang lain. Faktor biaya berkaitan dengan reputasi pekerja, akses lokasi proyek, dan jenis requirement alat yang digunakan dalam membangun rumah. Tingginya harga perumahan dipengaruhi oleh pekerja yang digunakan berasal dari kalangan profesional yang memiliki reputasi baik. Kemudian, mudahnya aksesibilitas serta mobilitas yang dimiliki lokasi proyek pembangunan rumah dapat meningkatkan harga perumahan. Hal ini sesuai dengan pendapat Swastha dan Irawan (2005), yang menyatakan bahwa salah satu faktor yang mempengaruhi tingkat harga adalah faktor biaya. Hasil penelitian ini didukung oleh penelitian yang dilakukan oleh Silalahi (2011), yang menyatakan bahwa perhitungan harga jual perumahan didasarkan faktor biaya. 
Keadaan perekonomian merupakan faktor penting yang mempengaruhi tingkat harga perumahan di Kabupaten Buleleng. $\mathrm{Hal}$ ini disebabkan karena keadaan perekonomian berkaitan dengan tingkat inflasi, tingkat resesi, dan tingkat suku bunga sangat mempengaruhi harga perumahan. Tingginya tingkat inflasi setiap tahunnya menyebabkan tingkat harga perumahan menjadi naik. Kemudian, tingginya tingkat resesi dalam penjualan perumahan dapat menyebabkan tingkat harga perumahan menjadi turun. Selanjutnya, tingginya tingkat suku bunga cicilan kredit menyebabkan tingkat harga perumahan menjadi naik. Hal ini sesuai dengan pendapat Swastha dan Irawan (2005), yang menyatakan bahwa salah satu faktor yang mempengaruhi tingkat harga adalah keadaan perekonomian. Hasil penelitian ini didukung oleh penelitian yang dilakukan oleh Kusuma (2017), yang menyatakan bahwa faktor yang mempengaruhi penetapan harga jual disesuaikan dengan kondisi ekonomi masyarakat, yaitu menyesuaikan dengan daya beli masyarakat.

Permintaan dan penawaran
merupakan faktor penting yang mempengaruhi tingkat harga perumahan di Kabupaten Buleleng. Hal ini disebabkan karena permintaan dan penawaran berkaitan dengan tingkat pendapatan, selera, jumlah penduduk, ekspektasi produsen atas harga barang tersebut di masa datang, dan jumlah perusahaan sejenis. Tingginya pendapatan per kapita dalam perekonomian daerah, kepuasan masyarakat, dan kepadatan jumlah penduduk di sekitar lokasi perumahan dapat menyebabkan tingkat harga perumahan menjadi naik. Kemudian, harga perumahan dipengaruhi harapan pengembang terhadap harga rumah di masa yang akan datang untuk meningkatkan penawaran dan semakin banyak jumlah developer yang bersaing pembangunan perumahan dapat meningkatkan harga perumahan. Hal ini sesuai dengan pendapat Swastha dan Irawan (2005), yang menyatakan bahwa salah satu faktor yang mempengaruhi tingkat harga adalah permintaan dan penawaran. Hasil penelitian ini didukung oleh penelitian yang dilakukan oleh Prasestya dan Sunaryo (2013), yang menyatakan bahwa harga dapat ditentukan melalui permintaan dan penawaran yang ada pada sebuah kawasan.

\section{SIMPULAN DAN SARAN Simpulan}

Berdasarkan hasil analisis data dan pembahasan hasil penelitian maka dapat ditarik simpulan sebagai berikut. Pertama, faktor-faktor yang mempengaruhi tingkat harga perumahan di Kabupaten Buleleng adalah faktor keadaan perekonomian memiliki eigenvalue 1.195 dengan nilai varian $17.073 \%$, faktor permintaan dan penawaran memiliki eigenvalue 1.024 dengan nilai varian $14.622 \%$, faktor elastisitas permintaan memiliki eigenvalue 0.433 dengan nilai varian $6.180 \%$, faktor persaingan memiliki eigenvalue 0.175 dengan nilai varian $2.495 \%$, faktor biaya memiliki eigenvalue 2.818 dengan nilai varian $40.262 \%$, faktor tujuan perusahaan memiliki eigenvalue 0.762 dengan nilai varian $10.882 \%$, dan faktor pengawasan pemerintah memiliki eigenvalue 0.594 dengan nilai varian $8.486 \%$.. Kedua, faktor yang paling dominan mempengaruhi tingkat harga perumahan di Kabupaten Buleleng adalah faktor biaya dengan varimax rotation sebesar $40.262 \%$.

\section{Saran}

Berdasarkan simpulan diatas, maka dapat dikemukakan beberapa saran sebagai berikut. Pertama, Bagi pengembang, mengingat bahwa biaya merupakan faktor yang paling dominan mempengaruhi tingkat harga perumahan di Kabupaten Buleleng, maka disarankan kepada pengembang untuk mengatur bahan-bahan yang digunakan untuk membangun rumah tanpa mempengaruhi kualitas dan desain rumah agar disesuaikan untuk mengurangi biaya sehingga harga rumah terjangkau bagi konsumen. Meskipun berusaha melakukan pengurangan biaya demi menurunkan harga, mutu hasil pengerjaan rumah harus ditingkatkan dengan tidak mengurangi fasilitas bangunan yang telah dianggap baik oleh konsumen. Hal ini jangan sampai melalaikan apa yang telah baik, justru harus 
semakin meningkatkan yang baik menjadi lebih baik. Kedua, Bagi peneliti lain yang mendalami mengenai faktor-faktor yang mempengaruhi tingkat harga perumahan diharapkan menggunakan faktor tempat/lokasi guna keberlakuan temuan ini secara lebih luas.

\section{DAFTAR PUSTAKA}

Arikunto, S. 2009. Prosedur Penelitian Suatu Pendekatan Praktik. Jakarta: Rineka Cipta.

Hidayah, Siti Muflikhatul. 2011. Penentuan Harga Jual Beli Dalam Ekonomi Islam. Skripsi. Universitas Muhammadiyah Surakarta.

Kotler, Philip. 2002. Manajemen Pemasaran, Jilid I, Edisi Indonesia, Edisi Milenium, Edisi Kesepuluh. Jakarta: PT. Prenhallindo.

Kotler, Philip dan Gary Armstrong. 2008. Prinsip-prinsip Pemasaran, Jilid I, Edisi 12. Jakarta: Erlangga.

Kotler, Philip dan Gary Armstrong. 2012. Prinsip-prinsip Pemasaran, Jilid I, Edisi 13. Jakarta: Erlangga.

Kusuma, RT. Sandra Novella. 2017. Tinjauan Hukum Ekonomi Syariah Dalam Faktor-faktor yang Mempengaruhi Harga Jual Air Minum di Perusahaan Daerah Air Minum (PDAM) Kota Cirebon. Skripsi. Institut Agama Islam Negeri (IAIN).

Prasestya, Nararya Adi dan PM. Broto Sunaryo. 2013. Faktor Faktor yang Mempengaruhi Harga Lahan di Kawasan Banjarsari Kelurahan Tembalang, Semarang. Jurnal Teknik PWK, 2(2), 223-232.

Silalahi, Mellisa D.Y. 2011. Faktor-faktor yang Mempengaruhi Penetapan Harga Jual Perumahan Pada PT Putera Karyasindo Prakarsa. Tugas Akhir. Program Studi Akuntansi, Jurusan Administrasi Niaga, Politeknik Negeri Batam.

Sugiyono. 2011. Metode Penelitian Kuantitatif Kualitatif dan $R \& D$. Bandung: Alfabeta.
Suliyanto. 2012. Analisis Data Dalam Aplikasi Pemasaran. Bogor: Ghalia Indonesia.

Swastha, Basu dan Irawan. 2005. Manajemen Pemasaran Modern, Edisi Ketiga, Yogyakarta: Liberty. 